\title{
Density-dependent predation by blue crabs upon infaunal clam species with contrasting distribution and abundance patterns
}

\author{
David B. Eggleston ${ }^{1, *}$, Romuald N. Lipcius ${ }^{1}$, Anson H. Hines ${ }^{2}$ \\ ${ }^{1}$ The College of William and Mary, School of Marine Science, Virginia Institute of Marine Science, Gloucester Point, \\ Virginia 23062, USA \\ ${ }^{2}$ Smithsonian Environmental Research Center, PO Box 28, Edgewater, Maryland 21037-0028, USA
}

\begin{abstract}
Adult infaunal clams (Macoma balthica) persist at low densities in sandy and muddy habitats in Chesapeake Bay, USA, despite intense predation by blue crabs Callinectes sapidus; another infaunal soft-shelled clam (Mya arenaria) only persists in sandy habitats. We hypothesized that the persistence of $M$. balthica and $M$. arenaria in certain habitats was due to blue crabs exhibiting a type III (sigmoid) functional response whereby the risk of mortality is reduced at low clam densities. Laboratory experiments assessed functional responses (prey consumption predator ${ }^{-1}$ as a function of prey density) of large male blue crabs to 6 densities of $M$. balthica as a function of sediment type (sand and mud) and tank size $(54.6 \mathrm{~cm}$ and $97.2 \mathrm{~cm}$ diameter). These results were compared with previous experiments with $M$. arenaria. Abundances of blue crabs, $M$. balthica, and $M$. arenaria were measured 4 to 10 times $\mathrm{yr}^{-1}$ from 1979 to 1986 at both sand and mud stations in the mesohaline zone of Chesapeake Bay. Laboratory functional response results were then related to seasonal habitat-specific abundance patterns of $M$. balthica and $M$. arenaria in the field. With the exception of $M$. balthica in mud, abundances of $M$. arenaria and $M$. balthica decreased as blue crab abundance increased during the summer. When blue crabs reached their peak abundances in July, $M$. balthica was predominant in mud whereas $M$. arenaria numbers dropped to zero in mud and persisted in sand at similar low densities to $M$. balthica in sand. In the laboratory, blue crabs exhibited density-dependent (type III) functional responses to $M$. balthica irrespective of sediment type and tank size, even though mortality rates of clams were significantly higher in sand than mud. Differences in habitat-specific burial depth probably accounted for the differential survival of $M$. balthica in sand and mud. Thus, $M$. balthica obtained a relative refuge from blue crab predation at low densities similar to those in the field near the end of the seasonal period of active predation. Previous laboratory experiments with blue crabs indicated a type III functional response to $M$. arenaria in sand and an inversely density-dependent type II response to $M$. arenaria in mud. Thus, the collective laboratory and field evidence from this study and others strongly suggests that blue crabs are critical determinants of species-and habitat-specific prey persistence in marine soft-bottom communities, and that analysis of predator functional and aggregative responses may help to explain much of the spatial variation of clam abundance patterns in the mesohaline zone of Chesapeake Bay.
\end{abstract}

\section{INTRODUCTION}

Predator-prey interactions in soft-bottom marine communities are complex because they are dominated by guilds of generalized predators capable of switch-

\footnotetext{
- Present address: College of Ocean and Fishery Sciences, WH-10, University of Washington, Seattle, Washington 98195, USA
}

ing among diverse prey, and because there are few communities with single competitively dominant prey capable of monopolizing resources (Virnstein 1977. Peterson 1979, Holland et al. 1980, Hines et al. 1990). In most marine systems, however, trophic complexities can be simplified to a relatively few strong interactions (Paine 1980). For example, experiments in Chesapeake Bay have examined predation by a dominant epibenthic predator - the blue crab Callinectes sapidus 
upon 2 abundant infaunal and broadly distributed, thin-shelled clams (Macoma balthica and Mya arenaria) to identify the key factors accounting for clam persistence despite intense predation (Blundon \& Kennedy 1982, Lipcius \& Hines 1986, Hines et al. 1990, Mansour \& Lipcius 1991). Blue crabs and $M$. balthica and $M$. arenaria often exhibit discordant population cycles in certain sedimentary habitats with peak clam abundances declining rapidly in summer when those of the blue crab increase dramatically (Hines et al. 1990). The clams are major components of the diet of the blue crab (Hines et al. 1990); however, large clams of both species persist in the field at great burial depth (ca 20 to $30 \mathrm{~cm}$; Hines \& Comtois 1985) and low densities $\left(0.2\right.$ to 19 clams $\mathrm{m}^{-2}$; Cory \& Redding 1977 , Blundon \& Kennedy 1982, Hines et al. 1990). Clam persistence appears to be species- and habitat-specific; both clams settle in sandy and muddy habitats, yet $M$ arenaria persists only in sand, whereas $M$. balthica survives in both habitats (Hines \& Comtois 1985, and see following).

The differential survival of Mya arenaria in mud and sand involves disproportionately low predation by the blue crab upon low densities of deep-dwelling $M$ arenaria in sand; conversely, predation is inversely density-dependent in mud, even at deep depths, thereby precluding a refuge (Lipcius \& Hines 1986 Lipcius unpubl.). Blue crabs search for prey by probing the substrate with the tips of their walking legs, where chemosensory and tactile setae are located. A reduction in crab encounter rates with $M$. arenaria due to reduced penetrability of sandy sediments was suggested as the behavioral mechanism underlying the differential survival of $M$. arenaria in sand versus mud (Lipcius \& Hines 1986). Reduced encounter rates may lead to lowered activity levels, which subsequently reduce encounter rates further, or result in emigration from areas of low clam density (Lipcius \& Hines 1986).

Habitat-specific survival and the mechanism underlying the persistence of Macoma balthica in both mud and sand have not been identified. We hypothesized that the persistence of $M$. balthica in both habitats was due to density-dependent predation by the blue crab. and thereby examined habitat-specific functional responses of the blue crab to $M$. balthica. In this investigation of blue crab predation upon $M$. balthica, using the functional response approach, we provide a comparison with patterns measured previously for Mya arenaria, and therefore an analysis of the relationship between predation by a key predator and the survival and persistence of prey species with contrasting distribution and abundance patterns.

The predator functional response, which describes the number of prey consumed per predator as a function of prey density (Solomon 1949, Holling 1959), quantitatively characterizes 1 of 2 key mechanisms underlying predator-prey dynamics (the other mechanism being the numerical response). The 2 most common forms of the functional response are Holling's (1959) type II and III categories. In the type II response, inversely density-dependent consumption rates rise with prey density at a decelerating rate to an upper asymptote, reflecting increased costs or constraints associated with higher consumption rates. The type III response is sigmoid, demonstrating density-dependent consumption rates at low to moderate prey densities. Sigmoid functional responses are to be expected whenever the 'reward rate' at the lowest prey densities is insufficient to maintain a constant searching rate (Hassell 1978). The key difference between type II and type III responses is that in the former, the risk of mortality increases with decreasing prey density, whereas in the latter, there is a change from an increasing to decreasing risk of mortality as prey density decreases (Lipcius \& Hines 1986). Hence, the type of functional response may identify potential behavioral mechanisms leading to local extinction or persistence of prey populations (Katz 1985, Lipcius \& I lines 1986 , Abrams 1987, Murdoch \& Bence 1987, Eggleston 1990a, b, c, Sponaugle \& Lawton 1990), and thereby is a powerful quantitative method for examining predatorprey dynamics under diverse environmental conditions.

\section{The predator-prey system}

The blue crab Callinectes sapidus Rathbun (Arthropoda: Crustacea: Portunidae) is a large (up to $280 \mathrm{~mm}$ carapace width; $\mathrm{CW}$ ) epibenthic omnivore found throughout diverse habitats along the Atlantic and Gulf coasts of North America (Williams 1984). Bivalve molluscs (predominantly Macoma balthica and Mya arenaria) form a major component of the diet (Laughlin. 1982, Alexander 1986, Hines et al. 1990). In Chesapeake Bay, blue crabs are abundant and forage actively from late spring through autumn, after which they overwinter buried in subtidal habitats (Van Engel 1958, Hines et al. 1987).

Macoma balthica (Mollusca: Bivalvia: Tellinidae) is an infaunal surface deposit-feeding and facultative suspension-feeding clam that grows to about $40 \mathrm{~mm}$ in shell length (SL) and occupies muddy and sandy bottoms (Hines \& Comtois 1985). In Chesapeake Bay, $M$. balthica is also deep-burrowing (depth to $30 \mathrm{~cm}$ ) and occurs predominantly in muddy substrates of meso-polyhaline regions (Hines \& Comtois 1985, Hines et al 1990). M. balthica displays relatively weak settlement in winter followed by a marked pulse peaking in May; populations decline rapidly in July and August primarily in association with intense blue crab preda- 
tion (Holland et al. 1980, 1987, Blundon \& Kennedy 1982, Holland 1985, Hines et al. 1987, 1990). Large, adult $M$. balthica attain a partial prey refuge at deeper depths (i.e. $>10 \mathrm{~cm}$; Blundon \& Kennedy 1982) and possibly at low densities, as observed for Mya arenaria (Lipcius \& Hines 1986).

Mya arenaria (Mollusca: Bivalvia: Myacidae) is an infaunal suspension-feeding clam that grows to about $80 \mathrm{~mm}$ shell length, burrows deeply (ca $30 \mathrm{~cm}$ ), and occurs primarily in sandier substrates of Chesapeake Bay (Hines \& Comtois 1985). M. arenaria abundance increases in late winter and spring after settlement periods, and decreases sharply when predators become active (Holland et al. 1980, Hines et al. 1990, and see following).

In this study we tested the effects of sediment composition upon the functional response of blue crabs feeding on Macoma balthica. The specific objectives were to (1) quantify seasonal habitat-specific abundance of blue crabs, and recruitment and abundance patterns of $M$. balthica and Mya arenaria in nature, (2) examine the effects of sand and mud on the functional response and associated behavioral parameters, and (3) relate these laboratory results to seasonal habitat-specific abundance patterns of $M$. balthica and $M$. arenaria in nature.

\section{METHODS AND MATERIALS}

\section{Long-term population fluctuations of crabs and} clams. Abundance of blue crabs and clams (Macoma balthica and Mya arenaria) was measured 4 to 10 times per year from October 1979 to December 1986 at both sand and mud stations (as described by Hines et al. 1987,1990 ) at the mouth of the Rhode River, Maryland, USA, (38 $\left.51^{\prime} \mathrm{N}, 76^{\circ} 32^{\prime} \mathrm{W}\right)$, a 485 ha subestuary of the lower mesohaline zone of Chesapeake Bay. SCUBA divers sampled clams by taking 10 cores of $0.008 \mathrm{~m}^{2}$ by $35 \mathrm{~cm}$ deep at haphazard locations within both sand and mud stations during each sampling period. Cores were sieved through $0.5 \mathrm{~mm}$ mesh and fixed in $10 \%$ formaldehyde with rose bengal. Numbers and shell length $(\mathrm{mm})$ of $M$. balthica and $M$. arenaria were recorded. Crab abundance was measured with an otter-trawl net of $5 \mathrm{~cm}$ mesh net body, $3 \mathrm{~m}$ wide mouth, $7 \mathrm{~mm}$ mesh cod end liner, and a tickler chain. Monthly trawls were pulled for a fixed distance of $900 \mathrm{~m}$ on 3 consecutive days at each sand and mud station. Winter samples (excluding January and February) were not taken because crabs are inactive and buried during the coldest portion of winter (Hines et al. 1987, 1990).

Monthly averages of crabs captured over the $6 \mathrm{yr}$ sampling period (1981 to 1986) were analyzed as the response variable in a 2-way fixed-factor ANOVA model with season (winter/spring: December to May and summer/fall: June to November) and sediment type (sand vs mud) as factors. Our choice of seasons (December to May vs June to November) for both crabs and clams (see below) was based upon seasonal trends in abundance over time that were apparent for most of the species by habitat combinations (see Figs. 1 \& 2 ). Monthly averages of both total numbers of clams (i.e. clams $>500 \mu \mathrm{m} \mathrm{SL}$ ) and adult clams (i.e. clams $>5 \mathrm{~mm}$ SL) of both species (Mya arenaria and Macoma balthica), over the $7 \mathrm{yr}$ sampling period, were each analyzed as the response variable in 2 separate 2 -way fixed-factor ANOVA models. The first model used season (winter/spring: December to May and summer/ fall: June to November) and sediment type (sand vs mud) as factors. The second model used sediment type (sand vs mud) and species ( $M$. balthica vs $M$. arenaria) as factors. In all cases, both total numbers of clams and adult were logarithmically transformed to standardize variances. Variances were tested for homogeneity with Cochran's C-test (Winter 1971) while differences between means were revealed with Ryan's $Q$ multiple comparison test (Einot \& Gabriel 1975). The Kramer modification of the Ryan's Q-test was used when sample sizes were uneven, as recommended by Day \& Quinn (1989).

Experimental procedure and design. Blue crabs were captured in traps from the lower York River, a major tributary of lower Chesapeake Bay $\left(37^{\circ} 14.5^{\prime} \mathrm{N}\right.$, $76^{\circ} 30.0^{\prime} \mathrm{W}$ ), and transferred to laboratory holding tanks where they were fed Macoma balthica ad libitum for 1 wk prior to experimental trials. Only large male intermolt crabs, representative of the dominant size-class in Chesapeake Bay (135 to $165 \mathrm{~mm} \mathrm{CW}$; Hines et al. 1990) that fed during the acclimation period were used in experiments. $M$. balthica (25 to $35 \mathrm{~mm} \mathrm{SL}$; the modal adult size-class) were collected with a suction pump from Kings Creek in the York River ( $37^{\circ} 17.3^{\prime} \mathrm{N}, 76^{\circ} 35.0^{\prime} \mathrm{W}$ ) and placed into holding tanks with flowing York River water as a food source.

Two laboratory experiments were then performed from July 6 to September 14, 1987 and August 7 to September 25, 1988 to examine the interactive effects of sediment type and prey density on consumption rates of blue crabs preying upon Macoma balthica During the experiment, 4 circular experimental tanks measuring $54.6 \mathrm{~cm}$ in diameter were filled with mud (20.0\% sand, $33.9 \%$ silt, $46.0 \%$ clay) and 4 with sand (94.2\% sand, $1.9 \%$ silt, $3.7 \%$ clay) to a level $24 \mathrm{~cm}$ above the tank bottom. The mud and sand were collected from field sites harboring populations of $M$. balthica; all clams were removed from the field sediments prior to introduction into experimental tanks.

Clams exhibiting vigorous siphon-withdrawal reflexes were buried in the tanks (5 $\mathrm{cm}$ deep) and allowed 
$48 \mathrm{~h}$ to bury further and thereby attain natural burial depths (15 to $20 \mathrm{~cm}$; Hines \& Comtois 1985) before exposure to crabs. Clams in control tanks were found 15 to $20 \mathrm{~cm}$ deep after the initial $48 \mathrm{~h}$ burial period. Clams were also placed 10 to $15 \mathrm{~cm}$ from the edge of the tank to avoid possible edge effects (i.e. crabs potentially consuming more or less clams from the periphery of experimental tanks). Feeding trials were initiated at 13:00 h when a single Callinectes sapidus was introduced into a tank, and ended upon removal of the crab $48 \mathrm{~h}$ later. Six experimental densities of $1,2,4$. 8,16 , and 24 clams tank $^{-1}$ (4.3 to 102.6 clams m$^{-2}$ ). representing the range of natural Macoma balthica densities of large clams ( 25 to $35 \mathrm{~mm}$ SL) in Chesapeake Bay (Hines et al. 1990), were replicated 6 to 10 times each. A single sand and mud control tank containing the highest clam density and no crab was tested for mortality unrelated to crab predation in each triai. This layout aliowed 8 experimental trials, each containing a randomly chosen combination of clam density and sediment type. Thus, each trial consisted of 6 feeding tanks and 2 control tanks. The numbers of surviving clams and umbos of eâten clams were counted to account for all experimental clams.

To ascertain whether the functional responses in the 1987 experiment were due to clam density and not tank size effects (e.g. de Lafontaine \& Leggett 1987), we performed an additional experiment in 1988 using the same range of low clam densities as in the previous experiment, but with larger experimental tanks. During the 1988 experiment, 8 circular tanks measuring $97.2 \mathrm{~cm}$ in diameter were used to examine the effects of sand and mud on the functional response of Callinectes sapidus to low Macoma balthica densities. We chose to examine only the lower range of clam densities in 1988 because density-dependent functional responses are detectable at low to moderate prey densities (see next section). We conducted 5 replicate trials at densities of 2,4 , and 8 clams tank $\mathrm{t}^{-1}$ (2.7 to 10.8 clams $\mathrm{m}^{-2}$ ) with the same experimental procedure described above.

During both experiments, salinities were 18 to $20 \mathrm{ppt}$, temperatures were 24 to $28^{\circ} \mathrm{C}$, and artificial lights maintained summer photoperiod at $14 \mathrm{~h}$ light:10 h dark. Clam survival in control tanks was $100 \%$ for both experiments.

Statistical analysis. Consumption rates (clams $\mathrm{crab}^{-1}$ $48 \mathrm{~h}^{-1}$ ) and proportional mortality rates [(no. clams eaten) (no. clams present) ${ }^{-1} \mathrm{crab}^{-1} 48 \mathrm{~h}^{-1}$ ], which were the response variables in both experiments, were analyzed with a 2-way fixed-factor ANOVA model using clam density and sediment type as factors. Proportional mortality was arc-sine square-root transformed to meet assumptions of normality and homogeneity of variance.
The shape of the proportional mortality curves as a function of prey density provides an accurate and quantitative definition of the type of functional response (Lipcius \& Hines 1986, Eggleston 1990a, b, c). Therefore, initial determination of the type of functional response (type II or III) was based on the results from the Ryan's $Q$ multiple comparison test of proportion mortality rates subsequent to the ANOVA. For example, a pattern with significantly higher proportional mortality rates at lower prey densities characterizes an inversely density-dependent, hyperbolic (type II) functional response (Hassell 1978), whereas a pattern of significantly lower proportional mortalities at low prey densities defines a density-dependent, sigmoid (type III) functional response (Hassell 1978).

Functional response modelling. Making direct observations of predator foraging behaviors such as prey handling time and predator attack rates is the optimal approach for revealing critical determinants of the functional response (e.g. Eggleston 1990a, b, Sponaugle \& Lawton 1990), particularly since calculation of these parameters based on theoretically derived curves may lead to erroneous conclusions (Valiela 1984). However, given the lack of visibility in our experimental tanks we were unable to make direct behavioral observations of blue crab foraging behaviors. Hence, we employed functional response models (see below) to estimate the basic behavioral components of predation (i.e. handling time and attack rates), thereby providing information for future comparison with actual behavioral observations. Parameter estimates based on functional response models have been shown to agree qualitatively with direct observation (Eggleston 1990 $a, b)$. However, we do not include these parameter estimates as a means for providing a behavioral interpretation of the functional responses measured in this study.

The continuous-time type II functional response model incorporates the basic behavioral components of predation - the rate of successful search (attack coefficient) and handling time - into the equation (Holling 1959):

$$
N_{e}=\frac{a^{\prime} T N_{\mathrm{t}}}{1+\left(a^{\prime} T_{\mathrm{h}} N_{\mathrm{t}}\right)}
$$

where the number of prey encountered per predator $\left(N_{e}\right)$ equals a function of the instantaneous attack rate $\left(a^{\prime}\right)$, total time available for foraging $(T)$, the number of prey available $\left(N_{\mathrm{l}}\right)$, and prey handling time $\left(T_{h}\right)$. Handling time includes the time from the initial encounter of the predator with prey, through the capture, ingestion and digestion of the prey, until searching resumes (Hassell 1978). The instantaneous attack rate $\left(a^{\prime}\right)$ is a measure of encounter success with prey. Because $a^{\prime}$ and $T_{\mathrm{h}}$ can vary as a function of each particular functional response model chosen (see below), 
reliable parameter estimates can be chosen only from the most appropriate and statistically valid model.

Discrete-time type II models integrate the instantaneous predation rate over the duration of the experiment $(T)$, assuming an exponential decay in prey density, and are appropriate in experiments where eaten prey are not replaced (e.g. the 'random predator' equation; Rogers 1972). Continuous-time type III models account for variation in search rate $\left(a^{\prime}\right)$ with density by substituting 2 parameters $(b, c)$ for $a^{\prime}$ in Eq. (1) (Hassell 1978). Type III discrete-time models are obtained similarly using the random predator equation (Hassell et al. 1977). A more detailed account of the different functional response models discussed above may be found in Hassell (1978) and Lipcius \& Hines (1986).

We used non-linear least squares model-fitting techniques (SAS Institute 1985) to estimate $a^{\prime}$ and $T_{h}$, and fit consumption rates from the 1987 experiment to the appropriate functional response models (i.e. continuous vs discrete-time models). We then described instantaneous attack rates $\left(a^{\prime}\right)$ across sediment treatments by calculating $a^{\prime}$ from a function of the $b$ and $c$ parameters from the continuous-time type III model; $a^{\prime}$ was calculated for each density as:

$$
a^{\prime}=\frac{b N_{t}}{1+\left(c N_{t}\right)}
$$

The statistical fit of continuous- and discrete-time functional response models was examined with an $F$ test employing the ratio of the lack-of-fit mean square to the pure error mean square (Neter \& Wasserman 1974, Trexler et al. 1988). A significant $F$-ratio indicated a statistically inadequate fit of the data to a model.

The criteria for determining a statistically valid functional response model, listed in decreasing priority, were: (1) $F$-value of the regression significant $(p<0.05)$; (2) lack-of-fit error non-significant ( $p>0.05)$; (3) lowest residual sum of squares of all models; and (4) residuals about the predicted values distributed randomly (see techniques in Lipcius \& Hines 1986).

Partial consumption of clams was not observed in any experiment, thereby precluding the need for nontraditional functional response models developed to account for 'wasteful killing' (Abrams 1982).

\section{RESULTS}

\section{Long-term population fluctuations of crabs and clams}

The abundance of blue crabs in the Rhode River differed significantly with season but not across habitat types (Table 1, Fig. 1). Mean number of crabs trawl ${ }^{-1}$ in both mud and sand increased steadily from early spring (March) through mid-summer (June/July), then declined steadily from mid-summer to late fall (November).

In general, both the total numbers of Macoma balthica and Mya arenaria ( $>500 \mu \mathrm{m} \mathrm{SL}$ ) and numbers of adult clams of both species ( $>5 \mathrm{~mm} \mathrm{SL}$ ) in the Rhode River varied significantly as a function of sediment type and season (Table 2a); however, the sediment type by

Table 1 Callinectes sapidus. Two-way ANOVA of logarithmically transformed numbers of crabs measured in the Rhode River from 1981 to 1986 describing the effects of sediment type (sand vs mud) and season (winter/spring: December to May vs summer/fall: June to November)

\begin{tabular}{|lrrrr|}
\hline Source of variation & SS & df & MS & \multicolumn{1}{c|}{$F$} \\
\hline Sediment type & 0.32 & 1 & 0.32 & $1.24 \mathrm{~ns}$ \\
Season & 3.17 & 1 & 3.17 & $12.21 \cdots$ \\
Sediment $\times$ season & 0.01 & 1 & 0.01 & $0.02 \mathrm{~ns}$ \\
Error & 21.80 & 84 & 0.26 & \\
& & & & \\
$\cdots \mathrm{p}<0.001 ; \mathrm{ns:} \mathrm{p}<0.05$ & & & & \\
\hline
\end{tabular}

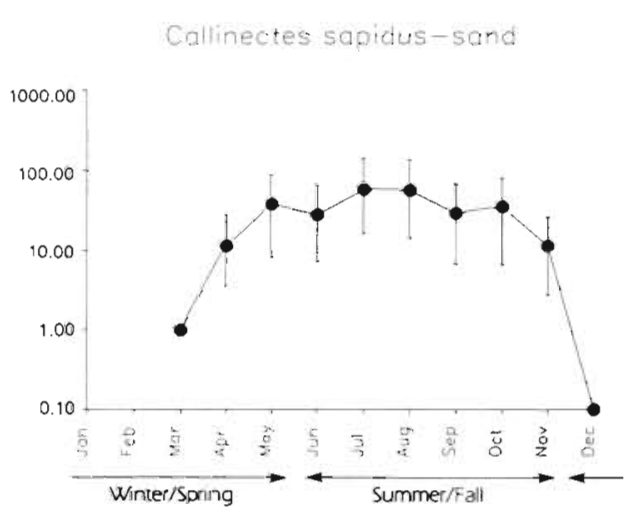

Fig. 1. Callinectes sapidus. Long-term (1979 to 1986) population cycles of blue crabs in mud and sand near the mouth of the Rhode River subestuary of Chesapeake Bay. Logarithmically transformed mean numbers ( \pm SE) of crabs per trawl are presented to clarify seasonal trends in abundance 
season interaction effects were significant in all cases precluding direct conclusions about the main effects (Underwood 1981), For $M$. balthica, the sediment by season interaction effect was due to a significant decrease in both the total numbers and numbers of adult clams during the summer and fall in sand but not in mud (Table 2b, Fig. 2). M. balthica densities remained rela-

Table 2a. Macoma balthica and Mya arenaria. Two-way ANOVA of logarithmically transformed numbers of clams measured in the Rhode River from October 1979 to December 1986 describing the effects of sediment type (sand vs mud) and season (winter/spring: December to May vs summer/ fall: June to November) on adult $M$. balthica ( $>5 \mathrm{~mm} \mathrm{SL}$ ), total no. $M$. balthica $(>500 \mu \mathrm{m})$, adult $M$. arenaria $(>5 \mathrm{~mm})$, and total no. $M$. arenaria $(>500 \mu \mathrm{m})$

\begin{tabular}{|c|c|c|c|c|}
\hline Source of variation & SS & $\mathrm{df}$ & MS & $F$ \\
\hline \multicolumn{5}{|l|}{ Adult Macoma balthica } \\
\hline Sediment type & 38.63 & 1 & 38.63 & $600.76 \cdots$ \\
\hline Season & 0.03 & 1 & 0.03 & $0.52 \mathrm{~ns}$ \\
\hline Sediment $\times$ season & 0.65 & 1 & 0.65 & $10.17 \cdots$ \\
\hline Error & 50.41 & 784 & 0.06 & \\
\hline \multicolumn{5}{|l|}{ Total Macoma balthica } \\
\hline Sediment type & 24.67 & 1 & 24.67 & $277.07 \cdots$ \\
\hline Season & 2.26 & 1 & 0.03 & $25.40 \cdots$ \\
\hline Sediment $\times$ season & 1.65 & 1 & 1.65 & $18.49 \cdots$ \\
\hline Error & 69.80 & 784 & 0.09 & \\
\hline \multicolumn{5}{|l|}{ Adult Mya arenaria } \\
\hline Sediment type & 1.64 & 1 & 1.64 & $53.06^{\cdots}$ \\
\hline Season & 2.46 & 1 & 2.46 & $79.37^{\cdots}$ \\
\hline Sediment $\times$ season & 1.09 & 1 & 1.09 & $35.27^{\cdots} \cdot$ \\
\hline Error & 23.93 & 773 & 0.03 & \\
\hline \multicolumn{5}{|l|}{ Total Mya arenaria } \\
\hline Sediment type & 5.80 & 1 & 5.80 & $103.36^{\cdots}$ \\
\hline Season & 3.22 & 1 & 3.22 & $57.43 \cdots$ \\
\hline Sediment $\times$ season & 0.77 & 1 & 0.77 & $13.71 \cdots$ \\
\hline Error & 43.35 & 773 & 0.06 & \\
\hline \multicolumn{5}{|c|}{$\because p<0.001 ; p<0.0001 ;$ ns: $p<0.05$} \\
\hline
\end{tabular}

Table 2b. Ryan's $Q$-test of log-transformed clam abundance for the sediment type by season interaction effect. Treatment levels that are not significantly different at $\mathrm{p}=0.05$ share an underline. Total numbers of clams $(>500 \mu \mathrm{m}$ SL) and adult clams (>5 mm) are not distinguished because the interaction effects were the same. Treatment levels are arranged in increasing order of abundance

\begin{tabular}{|c|c|c|}
\hline & \multicolumn{2}{|c|}{ Interaction } \\
\hline \multicolumn{3}{|l|}{ Macoma balthica } \\
\hline Winter/spring & mud & sand \\
\hline Summer/fall & mud & sand \\
\hline Mud & summer/fall & winter/spring \\
\hline Sand & summer/fall & winter/spring \\
\hline \multicolumn{3}{|l|}{ Mya arenaria } \\
\hline Winter/spring & sand & $\underline{\text { mud }}$ \\
\hline Summer/fall & sand & mud \\
\hline Mud & summer/fall & winter/spring \\
\hline Sand & summer/fall & winter/spring \\
\hline
\end{tabular}

tively high in mud throughout the summer and fall (Fig. 2). For $M$. arenaria, the sediment by season interaction effect was due to differences in the magnitude of the decrease in both total numbers and numbers of adult clams between mud and sand during the summer and fall (Table 2b, Fig. 2). In mud, the mean number of $M$. arenaria per core fluctuated from February to June and then dropped to zero in July, irrespective of whether the addition of new recruits was considered (i.e. a comparison of the total numbers of clams vs adult clams) (Fig. 2). Conversely, the decrease in the abundance of $M$. arenaria during the summer and fall in sand differed according to whether new recruits were considered (Table 2b). For example, although total numbers of $M$. arenaria in sand decreased from June to August, the magnitude of the decrease was higher for adult clams which dropped to essentially zero in August and October (Fig. 2). Thus, although clams settled in both sediment types, recruitment levels of $M$. arenaria were higher in sand than in mud whereas recruitment levels for $M$. balthica were higher in mud than sand (Fig. 2, compare total numbers of clams vs adult clams). Irrespective of recruitment levels, $M$. arenaria abundance was reduced to a seasonal low density within each sediment type, and $M$. balthica was reduced to a seasonal low abundance in sand (Fig. 2).

A comparison of clam abundance between each species within mud and sand indicated that both the total numbers of Macoma balthica and Mya arenaria (>500 $\mu \mathrm{m} \mathrm{SL}$ ) and the numbers of adult clams within each species (>5 mm SL) varied significantly as a function of sediment type and species (Table 3a); however, the sediment type by species interaction effects were significant in all cases, again precluding direct conclusions about the main effects. The sediment type by species interaction effect was due to differences in clam abundance between each clam species and within each sediment type. Numbers of $M$. balthica were significantly higher in mud than in sand, whereas numbers of $M$. arenaria were higher in sand than in mud (Table $3 b$ ). $M$. balthica was significantly more abundant than $M$. arenaria in mud, whereas the abundance of both species was similar in sand (Table $3 b$ ). Thus, when blue crabs reached their peak abundances in July, $M$. balthica was predominant in mud whereas numbers of $M$. arenaria plunged to zero in mud and persisted in sand at similar low densities to $M$. balthica in sand (compare Figs. 1 \& 2).

\section{Laboratory experiments: consumption and proportional mortality rates}

During the 1987 experiment, consumption rates differed significantly by Macoma balthica density and 


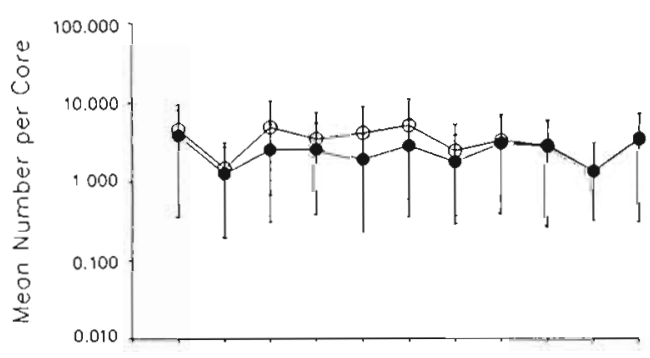

Mya arenario - mud

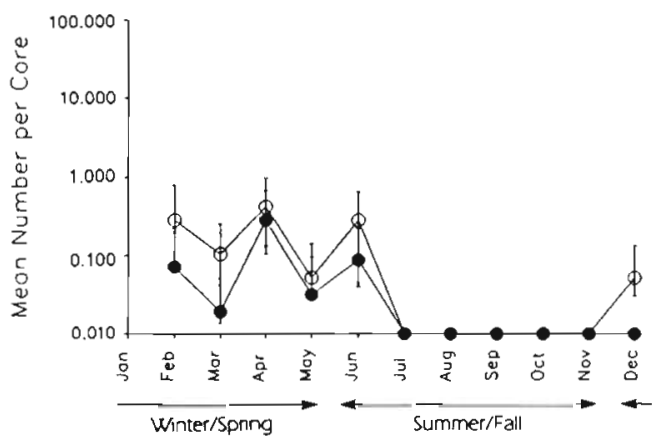

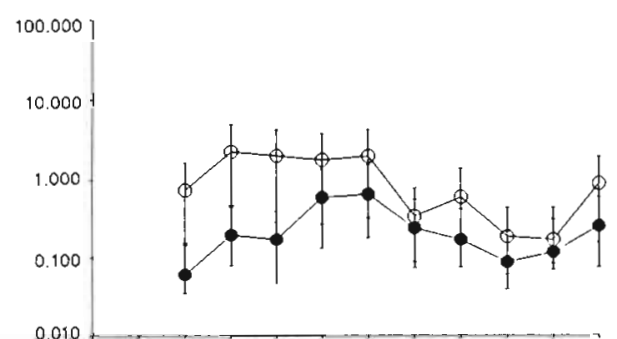

Myo arenaria - sond

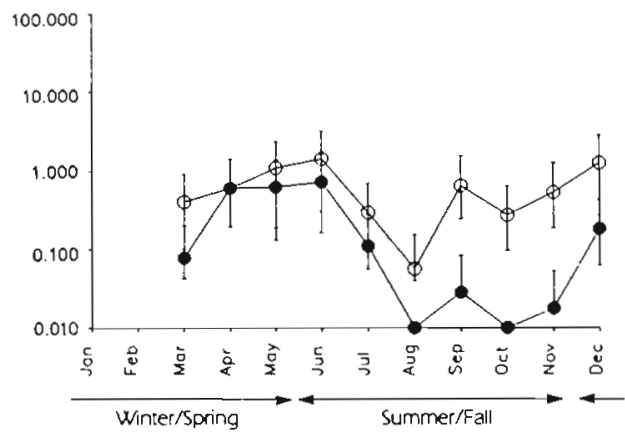

Fig. 2. Macoma balthica and Mya arenaria. Long-term (1979 to 1986) population cycles of infaunal clams near the mouth of the Rhode River subestuary of Chesapeake Bay. Mean number $( \pm \mathrm{SE}) 0.008 \mathrm{~m}^{-2}$ for $(\bullet$ clams $>5 \mathrm{~mm} \mathrm{SL}$ and $(0)$ clams $>500 \mu \mathrm{m} \mathrm{SL}$. Logarithmically transformed values are presented

sediment type (2-way ANOVA; clam density: $F=282.6$, $\mathrm{df}=5,71, \mathrm{p}<0.0001$; sediment type: $F=5.1$, df $=1,71$, $\mathrm{p}<0.027$ ); the interaction effect was not significant $(F=0.31$, df $=5.71, p=0.91)$ (Fig. 3a \& c). Consumption rates were higher in sand than mud, and increased significantly with clam density (Table 4).

Table 3a. Macoma balthica and Mya arenaria. Two-way ANOVA of logarithmically transformed numbers of clams measured in the Rhode River from October 1979 to December 1986 describing the effects of sediment type (sand vs mud) and clam species ( $M$. balthica vs $M$. arenaria) on adult clams (>5 mm SL), and total no. of clams $(>500 \mu \mathrm{m})$

\begin{tabular}{|lrrrr|}
\hline Source of variation & SS & df & MS & \multicolumn{1}{c|}{$F$} \\
\hline Adult clams & & & & \\
$\quad$ Sediment type & 1.11 & 1 & 1.11 & $36.53 \cdots$ \\
$\quad$ Species & 2.87 & 1 & 2.87 & $94.77 \cdots$ \\
Sediment $\times$ species & 3.16 & 1 & 3.16 & $104.48 \cdots$ \\
Error & 4.72 & 156 & 0.03 & \\
Total clams & & & & \\
Sediment type & 0.26 & 1 & 0.26 & 5.17 \\
Species & 4.00 & 1 & 4.00 & $80.80 \cdots$ \\
Sediment $\times$ species & 3.07 & 1 & 3.07 & $62.03 \cdots$ \\
Error & 7.73 & 156 & 0.05 & \\
•p<0.05; $\cdots \mathrm{p}<0.001 ; \mathrm{ns}: \mathrm{p}<0.05$ & & \\
\hline
\end{tabular}

Proportional mortality also differed significantly with clam density and sediment type (2-way ANOVA: clam density: $F=17.0, \mathrm{df}=5,71, \mathrm{p}<0.0001$; sediment type: $F=15.7, \mathrm{df}=1,71, \mathrm{p}<0.0001)$; the interaction effect was again not significant $(F=1.96$, df $=5,71, \mathrm{p}=0.10)$. Mean proportional mortality was significantly higher in sand than mud (Fig. 3b \& d). Proportional mortality in sand was significantly lower at the lowest clam densities compared with intermediate densities (Table 4). Similarly, proportional mortality in mud was significantly lower at the lowest prey density compared with

Table 3b. Ryan's Q-test of log-transformed clam abundance for the sediment type by clam species interaction effect. Treatment levels that are not significantly different at $p=0.05$ share an underline. Total no. of clams (>500 $\mu \mathrm{m} \mathrm{SL})$ and adult clams (>5 mm SL) are not distinguished because the interaction effects were the same. Treatment levels are arranged in increasing order of abundance

\begin{tabular}{|lcc|}
\hline \multicolumn{3}{|c|}{ Interaction } \\
\hline Macoma balthica & $\underline{\text { sand }}$ & $\underline{\text { mud }}$ \\
Mya arenaria & sand \\
Mud & Mya arenaria & Macoma balthica \\
Sand & Myarenaria & Macoma balthica \\
\hline
\end{tabular}



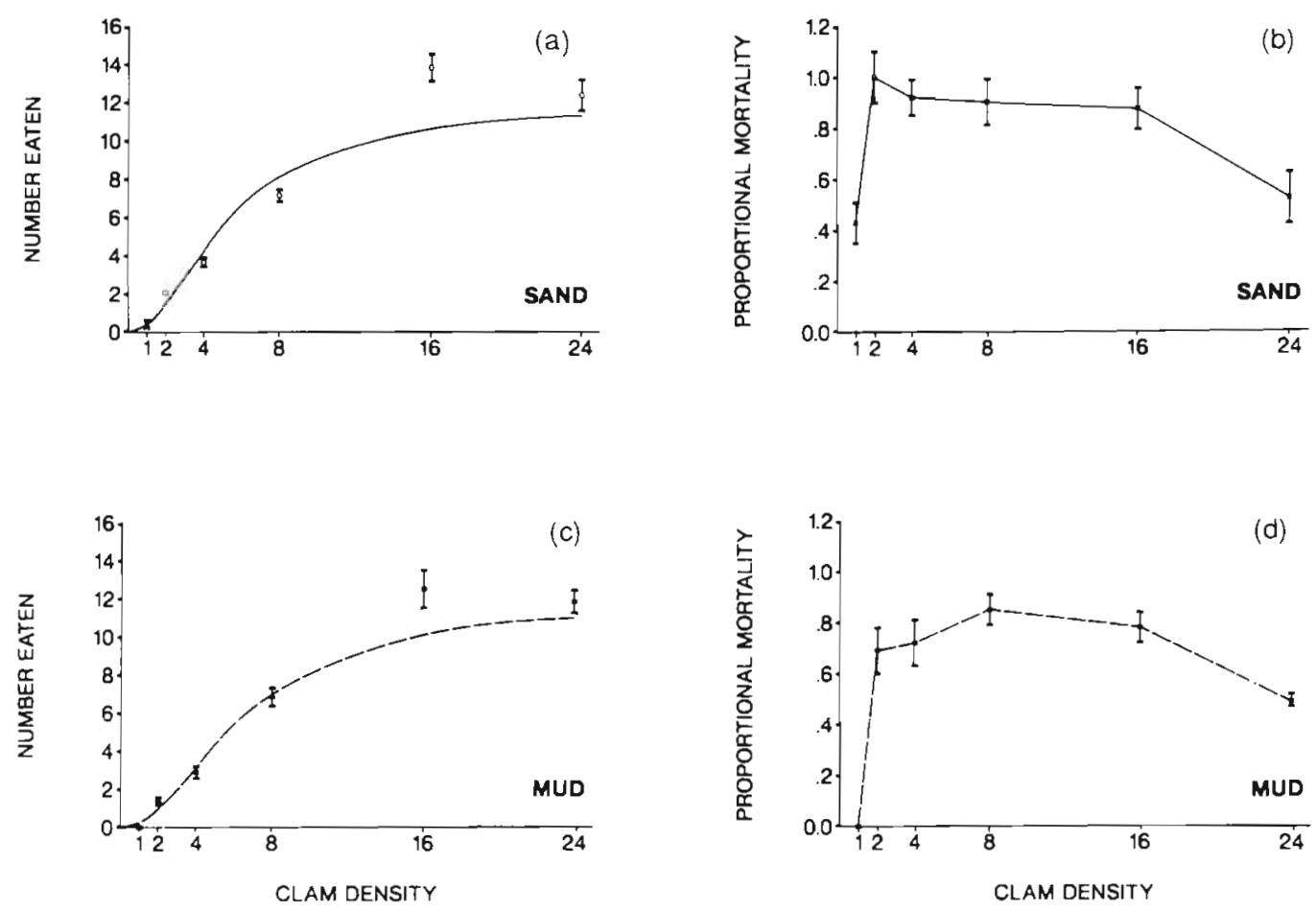

Fig. 3. Callinectes sapidus and Macoma balthica. (a \& c) Functional responses and (b \& d) associated proportional mortality rates for blue crabs feeding on 6 densities of clams in sand and mud in small tanks during the 1987 experiment. Fitted curves are from continuous-time type III functional response models (see Hassell 1978 for a description of the models). Means ( \pm SE) at each clam density are plotted

intermediate and high densities (Table 4 ). The results indicate a density-dependent, type III functional response, regardless of sediment type. Although density-dependent consumption rates were evident from 1 to 4 clams tank ${ }^{-1}$ in sand and mud, the magni- tude of density-dependent consumption differed between sediment types. For example, at $1 \mathrm{clam}^{t_{a n k}}{ }^{-1}$ ( 4.3 clams $\mathrm{m}^{-2}$ ), clams attained a total prey refuge from blue crab predation in mud compared to a partial refuge from predation in sand (Fig. 3).

Table 4. Macoma balthica. Results of Ryan's Q-test on mean consumption and arc-sine square-root transformed proportional mortality rates for clams in sand and mud trials in the 1987 experiment using small experimental tanks. Untransformed mean consumption rates (clams $\mathrm{crab}^{-1} 48 \mathrm{~h}^{-1}$ ) and proportional mortality rates [(no. clams eaten) (no. clams present) ${ }^{-1} \mathrm{crab}^{-1} 48 \mathrm{~h}^{-1}$ ] are presented as a function of clam density (clams $0.234 \mathrm{~m}^{-2}$ )

\begin{tabular}{|c|c|c|c|c|c|c|c|c|c|}
\hline \multirow[b]{2}{*}{$\mathrm{n}$} & \multicolumn{4}{|c|}{ Sand } & \multicolumn{5}{|c|}{ Mud } \\
\hline & $\begin{array}{l}\text { Clam } \\
\text { density }\end{array}$ & Consumption & $\begin{array}{c}\text { Clam } \\
\text { density }\end{array}$ & $\begin{array}{c}\text { Proportional } \\
\text { mortality }\end{array}$ & $\mathrm{n}$ & $\begin{array}{l}\text { Clam } \\
\text { density }\end{array}$ & Consumption $^{\mathrm{d}}$ & $\begin{array}{c}\text { Clam } \\
\text { density }\end{array}$ & $\begin{array}{c}\text { Proportional } \\
\text { mortality }\end{array}$ \\
\hline 7 & 1 & 0.43 & 1 & 0.437 & 6 & 1 & $0.00_{7}$ & 1 & 0.00 \\
\hline 8 & 2 & 2.00 & 24 & 0.52 & 8 & 2 & $1.38^{-1}$ & 24 & 0.49 \\
\hline 9 & 4 & 3.671 & 16 & $0.87]$ & 9 & 4 & 2.89 & 4 & 0.72 \\
\hline 6 & 8 & 7.171 & 8 & $0.90 \perp$ & 6 & 8 & 6.891 & 2 & 0.69 \\
\hline 7 & 24 & $12.40_{-}$ & 4 & 0.92 & 6 & 24 & 11.837 & 16 & 0.78 \\
\hline 5 & 16 & 13.86 & 2 & 1.00 & 6 & 16 & $12.50^{\rfloor}$ & 8 & 0.85 \\
\hline Me & $a n$ & 6.05 & & 0.77 & & & 5.46 & & 0.59 \\
\hline
\end{tabular}


Table 6. Summary statistics for nonlinear least-squares model-fitting of continuous and discrete-time functional response models for the 1987 experiment with Macoma balthica using small experimental tanks. NS: not significant

\begin{tabular}{|c|c|c|c|c|c|c|c|c|c|}
\hline Substrate & Source & SS & (df) & MS & $F$ & $\mathrm{p}$ & $R^{2}(\%)$ & $\begin{array}{l}\text { Binor } \\
\text { (partial) }\end{array}$ & $\begin{array}{l}\text { nial test } \\
\text { (complete) }\end{array}$ \\
\hline Sand & $\begin{array}{l}\text { Continuous-time type III model } \\
\text { Regression } \\
\text { Residual } \\
\text { Lack-of-fit } \\
\text { Pure error } \\
\text { Total }\end{array}$ & $\begin{array}{r}2487.4 \\
130.6 \\
12.9 \\
117.7 \\
2618.0\end{array}$ & $\begin{array}{l}(3) \\
(39) \\
(7) \\
(35) \\
(42)\end{array}$ & $\begin{array}{r}829.1 \\
3.3 \\
1.8 \\
3.4\end{array}$ & $\begin{array}{r}247.6 \\
0.5\end{array}$ & $\begin{array}{c}<0.0001 \\
\text { NS }\end{array}$ & 95.0 & NS & NS \\
\hline & $\begin{array}{l}\text { Discrete-time type III model } \\
\text { Regression } \\
\text { Residual } \\
\text { Lack-of-fit } \\
\text { Pure error } \\
\text { Total }\end{array}$ & $\begin{array}{r}2397.5 \\
220.5 \\
29.8 \\
190.7 \\
2618.0\end{array}$ & $\begin{array}{l}(1) \\
(41) \\
(7) \\
(35) \\
(42)\end{array}$ & $\begin{array}{r}2397.5 \\
5.4 \\
4.2 \\
5.4\end{array}$ & $\begin{array}{r}445.7 \\
0.7\end{array}$ & $\begin{array}{c}<0.0001 \\
\text { NS }\end{array}$ & 91.6 & $\mathrm{p}<0.001$ & $p<0.05$ \\
\hline Mud & $\begin{array}{l}\text { Continuous-time type III model } \\
\text { Regression } \\
\text { Residual } \\
\text { Lack-of-fit } \\
\text { Pure error } \\
\text { Total }\end{array}$ & $\begin{array}{r}2106.2 \\
97.8 \\
6.9 \\
90.9 \\
2204.0\end{array}$ & $\begin{array}{l}(3) \\
(38) \\
(7) \\
(34) \\
(41)\end{array}$ & $\begin{array}{r}702.1 \\
2.6 \\
1.0 \\
2.7\end{array}$ & $\begin{array}{r}27.3 .2 \\
0.4\end{array}$ & $\begin{array}{c}<0.0001 \\
N S\end{array}$ & 95.6 & NS & NS \\
\hline & $\begin{array}{l}\text { Discrete-time type III model } \\
\text { Regression } \\
\text { Residual } \\
\text { Lack-of-fit } \\
\text { Pure error } \\
\text { Total }\end{array}$ & $\begin{array}{r}2022.1 \\
181.9 \\
20.5 \\
161.4 \\
2204.0\end{array}$ & $\begin{array}{l}(2) \\
(39) \\
(7) \\
(34) \\
(41)\end{array}$ & $\begin{array}{r}1011.0 \\
4.7 \\
2.9 \\
4.7\end{array}$ & $\begin{array}{r}192.7 \\
0.6\end{array}$ & $\begin{array}{c}<0.0001 \\
\mathrm{NS}\end{array}$ & 91.7 & $p<0.005$ & NS \\
\hline
\end{tabular}

summer declines of previously recruited $M$. balthica coincide each year with the influx of blue crabs (Hines et al. 1990). However, cownose rays Rhinoptera bonasus may be important predators in the higher salinity zones of Chesapeake Bay (Smith \& Meriner 1985, Blaylock 1989). A combination of environmental and biotic factors may also affect persistence of $M$. balthica in certain habitats, including summer anoxia (Seliger et al. 1985), and gradients in salinity and temperature (Appeldoorn 1983). Disease does not appear to be an important source of mortality for
M. balthica in this system (Gibbons \& Blogoslawski 1989). Thus, regional persistence of $M$. balthica and Mya arenaria appears to depend upon densitydependent blue crab-induced mortality modified by local environmental conditions, as well as life history characteristics of local populations (Lipcius \& Hines 1986, this study; see also Zajac \& Whitlach 1985, Baird \& Ulanowicz 1989).

Results from this study suggest that the persistence of Macoma balthica in both sand and mud habitats in the mesohaline zone of Chesapeake Bay may be due to

Table 7 . Estimated model parameters for a continuous-time type III functional response model for sand and mud trials in the 1987 experiment using small experimental tanks. Instantaneous attack rates ( $a^{\prime}$, the area a predator searches for prey per unit time) were calculated with Eq. (2) using the $b$ and c parameters generated from a continuous-time type III functional response model (Hassell 1978). $T_{\mathrm{h}}$ : time (in $\mathrm{h}$ ) taken to break open and eat a single prey; $b, c$ : parameters replacing $a^{\prime}$ in the type III model. Values are means $\pm 1 \mathrm{SE}$

\begin{tabular}{|ccccc|}
\hline Sediment & \multicolumn{2}{c}{ Model parameters } & $c$ & $T_{h}$ \\
\hline Sand & $a^{\prime}$ & $b$ & $0.009 \pm 0.004$ & $4.00 \pm 0.02$ \\
Mud & $0.071 \pm 0.002$ & $0.009 \pm 0.002$ & $0.001 \pm 0.004$ & $4.06 \pm 0.03$ \\
\hline
\end{tabular}


density-dependent functional responses of blue crabs in both habitats. Blue crabs exhibited densitydependent type III functional responses to $M$. balthica irrespective of sediment type or tank size. Thus, adult $M$. balthica obtained a relative prey refuge from Callinectes sapidus predation at low clam densities in both sand and mud. Our low $M$. balthica experimental densities ( 4.3 to 17.1 clams $\mathrm{m}^{-2}$ ) were similar to those reported for large $M$. balthica (25 to $35 \mathrm{~mm} \mathrm{SL}$ ) surviving until autumn in Chesapeake Bay in muddy ( 5 to 25 clams $\mathrm{m}^{-2}$ ) and sandy ( 1 to 10 clams $\mathrm{m}^{-2}$ ) sediments (Hines \& Comtois 1985).

In an analogous study, blue crabs exhibited differing functional responses when preying upon Mya arenaria in sand and mud, with type II (inversely densitydependent) functional response in mud, but a type III (density-dependent) functional response in sand (Lipcius \& Hines 1986). These laboratory experiments indicated that natural populations of deeper dwelling $M$. arenaria were more likely to persist at low densities in sandy habitats because of reduced predation rates by Callinectes sapidus, whereas in mud $M$. arenaria become locally extinct due to high predation rates at low clam densities (Lipcius \& Hines 1986). Similarly, foraging efficiency by the blue crab and another portunid crab, Ovalipes ocellatus, upon hard clams Mercenaria mercenaria was reduced in a sand/shell substrate compared to a sand substrate, particularly at low clam densities (Sponaugle \& Lawton 1990). Thus, hard clams may also achieve a relative prey refuge at low densities in sand/shell habitats (Sponaugle \& Lawton 1990).

\section{Potential factors underlying variable functional responses}

Deep burial depth by Macoma balthica and Mya arenaria $(>15 \mathrm{~cm}$ ) appears critical to the attainment of a partial or absolute prey refuge at low clam densities in mud or sand. For example, field observations from the Rhode River indicate that low densities of adult $M$. balthica do not persist at shallow depths $(<10 \mathrm{~cm})$ (Hines \& Comtois 1985). Conversely, high densities of M. balthica do not persist at deep depths (Hines \& Comtois 1985). Thus, persistence of $M$. balthica in both mud and sand and of $M$. arenaria in sand is apparently due to the interactive effects of burial depth and clam density.

We hypothesize that the effects of burial depth and clam density upon blue crab encounter rates and attack success with clams may be further modified by (1) habitat-specific burial depth (Macoma balthica in sand vs mud) and (2) species-specific siphon size ( $M$. balthica vs $M$. arenaria). Blue crabs in this study exhibited density-dependent type III functional responses irrespective of sediment type, even though mortality rates of $M$. balthica were significantly higher in sand than mud. Mortality risk of infaunal bivalves due to crab predation decreases for individuals living at deeper burial depths (Reise 1979, Pearson et al. 1981, Blundon \& Kennedy 1982, Haddon et al. 1987). Since adult $M$. balthica reside at shallower depths in sand than mud (Hines unpubl.), blue crabs may have had higher successful encounter rates with these clams in sand. Direct observations are needed to verify this proposed depth-related mechanism.

Results from our long-term field observations indicated that Macoma balthica generally survived better during the summer when blue crabs were most abundant than Mya arenaria (Fig. 2), although this trend was only significant for clams in mud. Differential survival between $M$. balthica and $M$. arenaria was probably not due to differences in burial depth, since both species reside at similar depths (ca 20 to $25 \mathrm{~cm}$; Blundon \& Kennedy 1982, Hines \& Comtois 1985), but rather to differences in crab encounter rates with clam siphons. If siphon contact is the mechanism by which a crab locates a clam, then the relatively small siphon size of $M$. balthica (compared to $M$. arenaria) may present a smaller target to foraging blue crabs thereby resulting in reduced encounter rates relative to $M$. arenaria. For instance, whereas $M$. arenaria invests 40 to $50 \%$ of its body weight into siphon mass $[22 \mathrm{~mm} \mathrm{SL}$, siphon weight ca $25 \mathrm{mg}$ Ash Free Dry Weight (AFDW)], $M$. balthica invests only 1 to $4 \%(22 \mathrm{~mm} \mathrm{SL}$, siphon weight ca $1.2 \mathrm{mg}$ AFDW) (Zwarts \& Wanink 1989). Reduced encounter rates due to the small siphons of $M$. balthica may lead to lowered crab activity levels, which subsequently reduce encounter rates further, or result in emigration by crabs from areas of low prey density. A reduction in successful encounter rates or an increase in emigration rates at low $M$. balthica densities could lead to a type III functional response irrespective of sediment type. As above, direct behavioral observations are needed to verify this hypothesis.

\section{Alternative factors and long-term predator-prey dynamics}

Our laboratory studies were aimed at examining the correspondence between patterns of blue crab functional responses to Mya arenaria and Macoma balthica and the distribution and abundance patterns of these clam in the field. We focused on the effects of clam density and microhabitat features as a means of explaining the persistence of these clam species in particular sedimentary environments. However, it is important to realize that functional responses are only 
one element in an array of factors influencing the dynamics of interacting populations. Additional factors influencing blue crab-clam dynamics likely include time of settlement, magnitude of settlement (Hines et al. 1990) and the predator numerical response (Solomon 1949, Hassell \& May 1974) and mutual interference (Hassell 1978, Mansour \& Lipcius 1991).

Long-term population fluctuations of Callinectes sapidus and Macoma balthica indicate that there have been 2 levels of clam population density: (1) a high level during a period of years with moderate crab densities following a major increase in clam recruitment, and (2) a low level which occurred both when clam recruitment and crab abundances were moderate, or when clam recruitment was moderate and crab abundance was high (Hines et al. 1990). Predation on small clams affects the number of clam recruits to the large clam population, and the number of surviving large, reproductive clams affects both larval production possibly through stock-recruitment relationships and larval settlement through adult-larval interactions (Hines et al. 1989). Thus, it is critical that future attempts to model blue crab-clam predator-prey dynamics in this system address between-generation responses of crabs to clams.

The aggregative response describes changes in the foraging efficiency of predators as a function of both predator and prey density (Holling 1959, Hassell \& May 1974). Recent laboratory experiments examining the aggregative response of blue crabs to varying densities of Macoma balthica indicated (1) the maintenance of a low density refuge for clams, irrespective of crab density, and (2) intraspecific aggression resulting in injury and mortality of blue crabs at high crab densities (Mansour \& Lipcius 1991). The aggregative response of Callinectes sapidus to Mya arenaria is presently unknown. Nevertheless, the density-dependent functional responses of $C$. sapidus to $M$. balthica and $M$. arenaria (this study, Lipcius \& Hines 1986), and density-dependent aggregative response of blue crabs to $M$. balthica (Mansour \& Lipcius 1991), are in strong accord with the long-term patterns of persistence of $M$. balthica in sand and mud, and $M$. arenaria in sand. Moreover, recent field experiments in both the mesoand polyhaline zones of Chesapeake Bay (which will be reported on elsewhere) verified the long-term. survival patterns observed in the Rhode River $M$. balthica persisted at low densities in sand and mud whereas $M$. arenaria only persisted at low densities in sand (Lipcius, Hines \& Eggleston unpubl.). Clarns of both species survived equally well in caged control plots, irrespective of clam density and sediment type (Lipcius, Hines \& Eggleston unpubl.). Thus, epibenthic predators such as the blue crab are apparently critical determinants of species-and habitat-specific prey per- sistence in marine soft-bottom communities. Results from this study suggest potential behavioral mechanisms linking predator-prey interactions in this system, and further illustrate the need to specify the subtle characteristics of the habitat and prey that influence predator-prey dynamics. Moreover, analysis of the functional and aggregative responses appears to provide a mechanistic framework for explaining much of the spatial variation in predator and prey abundance patterns.

Acknowledgements. We thank C. Cox, A. M. Haddon, R. Mansour, L. Marshall, K. Metcalf, E. Olmi, and L. Wiechert for help with field collections of clams. Critical reviews of the manuscript were provided by R. Diaz, M. Luckenbach, C. Peterson and 2 anonymous referees. This work was financially supported by funds from the National Science Foundation (Biological Oceanography grant no. OCE 8700414 to R.L. and A.H. ), L. L. Glucksman, the Commonwealth of Virginia, the National Undersea Research Program of the National Oceanic and Atmospheric Administration (D.E.), the College of Ocean and Fishery Sciences of the University of Washington (D.E.), and the Smithsonian Environmental Sciences Program (A.H.). Contribution No. 1724 from the Virginia Institute of Marine Science.

\section{LITERATURE CITED}

Abrams, P. (1982). Functional responses of optimal foragers. Am. Nat. 120: $382-390$

Abrams, P. (1987). Indirect interactions between species that share a predator: varieties of indirect effects. In: Kerfoot, W., Sih, A. (eds.) Predation: direct and indirect impacts on aquatic communities. Univ. Press of New England, Hanover, New Hampshire, p. 38-54

Alexander, S. K. (1986). Diet of the blue crab, Callinectes sapidus Rathbun, from nearshore habitats of Galveston Island, Texas. Texas J. Sci. 38: 85-89

Appeldoorn, R. S. (1983). Variation in growth rate of Mya arenaria and its relationship to the environment as analyzed through principal components analysis and the parameter of the von Bertalanffy equation. Fish. Bull. U.S 81: $75-84$

Baird, D., Ulanowicz, R. E. (1989). The seasonal dynamics of Chesapeake Bay ecosystem. Ecol. Monogr. 59: 329-364

Blaylock, R. A. (1989). A massive school of cownose rays, Rhinoptera bonasus (Rhinopteridae), in lower Chesapeake Bay, Virginia. Copeia 3: 744-748

Blundon, J. A., Kennedy, V. S. (1982). Refuges for infaunal bivalve from blue crab Callinectes sapidus (Rathbun) predation in Chesapeake Bay. J. exp. mar. Biol. Ecol. 65 $67-81$

Cory, R. L., Redding, J. M. (1977). Mortalities caused by tropical storm Agnes to clams and oysters in the Rhode River area of Chesapeake Bay. In: The effects of tropical storm Agnes on the Chesapeake Bay estuarine system, Chesapeake Research Consortium Publication Number 54 Johns Hopkins University Press, Baltimore, p. 478-487

Day, R. W., Quinn, G. P. [1989]. Comparisons of treatments after an analysis of variance in ecology. Ecol. Monogr. 59 : $433-463$ 
de Lafontaine, Y., Leggett, W. C. (1987). Effect of container size on estimates of mortality and predation rates in experiments with macrozooplankton and larval fish. Can. J. Fish. Aquat. Sci. 44: 1534-1543

Eggleston, D. B. (1990a). Foraging behavior of the blue crab, Callinectes sapidus, on juvenile oysters Crassostrea virginica: effects of prey density and size. Bull mar. Sci. 46: $62-82$

Eggleston, D. B. (1990b). Behavioural mechanisms underlying variable functional responses of blue crabs, Callinectes sapidu feeding on juvenile oysters, Crassostrea virginica. J. Anim. Ecol. 59: 615-630

Eggleston, D. B. (1990c). Functional responses of blue crabs Callinectes sapidus Rathbun feeding on juvenile oysters Crassostrea virginica (Gmelin): effects of predator sex and size, and prey size. J. exp. mar. Biol. Ecol. 143: $73-90$

-Einot, I., Gabriel, K. R. (1975). A study of the powers of several methods of multiple comparisons. J. Amer. Stat. Assoc. 70: $574-583$

Gibbons, M. C., Blogolawski, W. J. (1989). Predators, pests, parasites and diseases. In: Manzi, J. J., Castagna, M. (eds.) Clam mariculture in North America: developments in aquaculture and fisheries science, Vol. 19. Elsevier Science Publishers, A. H. Amsterdam, p. 167-200

Haddon, M., Wear, R. G., Packer, H. A. (1987). Depth and density of burial by the bivalve Paphies ventricosa as refuges from predation by the crab Ovalipes catharus. Mar. Biol. 94: 25-30

Hassell, M. P. (1978). The dynamics of arthropod predatorprey systems. Monogr. Pop. Biol., Princeton Univ. Press, Princeton

Hassell, M. P., Lawton, J. H., Beddington, J. (1977). Sigmoid functional responses by invertebrate predators and parasitoids. J. Anim. Ecol. 46: 249-262

Hassell, M. P., May, R. M. (1974). Stability in insect-host parasite models. J. Anim. Ecol. 42: 693-736

Hines, A. H., Comtois, K. (1985). Vertical distribution of estuarine infauna in sediments of central Chesapeake Bay. Estuaries 8: 251-261

Hines, A. H., Haddon, A. M., Weichert, L. A. (1990). Guild structure and foraging impact of blue crabs and epibenthic fish in a subestuary of Chesapeake Bay. Mar. Ecol. Prog. Ser. 67: 105-126

Hines, A. H., Lipcius, R. N., Haddon, A. M. (1987). Population dynamics and habitat partitioning by size, sex, and molt stage of blue crabs Callinectes sapidus in a subestuary of Chesapeake Bay. Mar. Ecol. Prog. Ser. 36: 55-64

Hines, A. H., Posey, M., Haddon, P. (1989). Effects of adult suspension- and deposit feeding bivalves on recruitment of estuarine infauna. Veliger 32: 109-119

Holland, A. F. (1985). Long-term variation in macrobenthos in mesohaline region of Chesapeake Bay. Estuaries 8: $93-113$

Holland, A. F., Mountford, N. K., Hiegel, M. H., Kaumeyer, K. R. Mihursky, K. A. (1980). Influence of predation on infaunal abundance in upper Chesapeake Bay, USA. Mar. Biol. 57: 221-235

Holland, A. F., Shaughnessy, A. T., Hiegel, M. H. (1987). Long-term variation in mesohaline Chesapeake Bay macrobenthos: spatial and temporal patterns. Estuaries 10: $227-245$

Holling, C. S. (1959). The components of predation as revealed by a study of small mammal predation of the European pine sawfly. Can. J. Ent. 91: 293-320

Katz, C. H. (1985). A nonequilibrium predator-prey interaction. Ecology 66: 1426-1438
Laughlin, R. A. (1982). Feeding habits of the blue crab, Callinectes sapidus Rathbun, in the Apalachicola estuary. Fla. Bull. mar. Sci. 32: 807-822

Lipcius, R. N., Hines, A. H. (1986) Variable functional responses of a marine predator in dissimilar homogeneous microhabitats. Ecology 67: 1361-1371

Mansour, R. A., Lipcius, R. N. (1991). Density-dependent foraging and mutual interference in blue crabs preying upon infaunal clams. Mar. Ecol. Prog. Ser 72: 239-246

Murdoch, W. W., Bence, J. R. (1987). General predators and unstable prey populations. In: Kerfoot, W., Sih, A. (eds.) Predation: direct and indirect impacts on aquatic communities. Univ. Press of New England, Hanover, New Hampshire, p. 17-31

Neter, J., Wasserman, W. (1974). Applied linear statistical models: regression, analysis of variance, and experimental design. Irwin, Homewood, Illinois

Paine, R. (1980). Food webs: linkage, interaction strength and community infrastructure. J. Anim. Ecol. 49: 667-685

Pearson, W. H., Woodruff, D. L., Sugarman, P. C., Olla, B. L. (1981). Effects of oiled sediment on predation on the littleneck clam, Protothaca staminea, by the dungeness crab, Cancer magister. Estuar. coast Shelf Sci. 13: 445-454

Peterson, C. H. (1979). Predation, competitive exclusion, and diversity in the soft sediment communities of estuaries and lagoon. In: Livingston, R. J. (ed.) Ecological processes in coastal and marine systems. Plenum Publishing Co., New York, p. 233-264

Reise, K. (1979). Moderate predation on meiofauna by the macrobenthos of the Wadden Sea. Helgoländer wiss. Meeresunters. 32: 453-465

Rogers, D. (1972). Random search and insect population models. J. Anim. Ecol. 41. 369-383

SAS Institute. (1985). SAS user's guide: statistics. SAS Institute, Cary, North Carolina

Seliger, H. H., Boggs, J. A., Biggley, W. H. (1985). Catastrophic anoxia in the Chesapeake Bay in 1984. Science 228: $70-73$

Smith, JW., Merriner, J. V. (1985). Food habitats and feeding behavior of the cownose ray, Rhinoptera bonasus, in lower Chesapeake Bay. Estuaries 8: 305-310

Solomon, M. E. (1949). The natural control of animal populations. J. Anim. Ecol. 18: 1-35

Sponaugle, S., Lawton, P. (1990). Portunid crab predation on juvenile hard clams: effects of substrate type and prey density. Mar. Ecol Prog. Ser. 67: 43-53

Trexler, J. C., McCulloch, C. E., Travis, J. (1988). How can functional response best be determined? Oecologia 76 : $206-214$

Underwood, A. J. (1981). Techniques of analysis of variance in experimental marine biology and ecology. Oceanogr. mar. Biol. A. Rev. 19: 513-605

Valiela, I. (1984). Marine ecological processes. SpringerVerlag, New York

Van Engel, W. A. (1958). The blue crab and its fishery in the Chesapeake Bay, Part I. Reproduction, early development, growth and migration. Comm. Fish. Rev. 20:6-17

Virnstein, R. W. (1977). The importance of predation by crabs and fishes on benthic infauna in Chesapeake Bay. Ecology 58: $1199-1217$

Williams, A. B. (1984). Shrimps, lobsters, and crabs of the Atlantic coast of the eastern United States, Maine to Florida. Smithsonian Institution Press, Washington, DC

Winer, B. J. (1971). Statistical principles in experimental design, 2nd edn. McGraw-Hill, New York

Wolcott, T. G., Hines, A. H. (1990). Ultrasonic telemetry of small-scale movements and microhabitat selection by 
molting blue crabs (Callinectes sapidus). Bull mar. Sci. 46 $83-94$

Zajac, R. N., Whitlach, R. B. (1985). A hierarchical approach to modelling soft-bottom successional dynamics. In: Gibbs, P. E. (ed.) Nineteenth European Marine Biology Symposium. Cambridge University Press, Cambridge,

This article was presented by C. H. Peterson, Morehead City, North Carolina, USA
England, p. 265-276

Zar, J. H. (1984). Biostatistical analysis. Prentice-Hall, Inc., Englewood Cliffs, New Jersey

Zwarts, L., Wanink, J. (1989). Siphon size and burying depth in deposit- and suspension-feeding benthic bivalves. Mar. Biol. 100: 227-240

Manuscript first received: August 19, 1991

Revised version accepted: April 24, 1992 